\title{
A Framework for Employability Skills of Graduate in Malaysian Interior Design
}

\author{
Ahmad Alzabadani Alrifa ${ }^{1}$, Valliappan Raju ${ }^{2}$ \\ Limkokwing University of Creative Technology, Malaysia ${ }^{1,2}$
}

\begin{abstract}
The main objective of this research was to develop a framework for employability skills in interior design education curriculum. This research found three concepts of employability skills which include soft skills, hard skills and personal attributes from the literature. Also, from the survey, this research found framework which include of soft skills, hard skills and personal attribute skills which were later on merged to form the framework of employability skills. The discussions of findings were presented according to the research questions. The objectives of the study were to determine the relationship between design graduates' skills (soft skills, hard skills and personal attributes) and employers' satisfaction. This chapter also presented the discussion of independent ad dependent variable and also the research findings according to research questions, conclusion, implications of findings, recommendations and suggestions for further studies
\end{abstract}

Keywords: Pre-graduate-experience, Employability, University graduates, hard skills, soft skills, Interior Design, Malaysia

\section{INTRODUCTION}

Globalisation makes graduate recruitment to get an organisation technical. Employers believe a work force that is competitive is a key into this achievement of a firm. Although graduates are believed to own great specific skills, they still suffer from employability skills, and their job's standard affects. The company world today is extremely competitive. National surveys consistently indicate that organizations have difficulty finding employees with the ideal skills $[1,2,3]$.

Research analysing the consequences of graduate instruction after graduates' transition into the work force has been studied as the 1990s. This was once the career success of graduates started initially to be implemented as a crucial index to measure the quality of education in general, and degree specifically [4].

Improving graduates' employability converted. The wants of the labour market changed due to technological advancements in addition to the globalisation with this economy. These generated doubts at the labour market, which left it unclear about what skill sets, also, were needed for faculty graduates to generate a successful transition into the work force. Recently, the government and also the researchers have led the way in researching the relationship between employability skills and additionally industry.

Generally speaking, many scholars [5] discovered that equipping with acceptable employability skills make a major difference by potential recruiters also to the prosperity of participants of the work force. Current evidence suggests that investment in growing skills is connected with gains in quality of graduates and growth has higher returns to occur when growth is followed closely by individual resource clinics [6].

Moreover, there's a wholesome relationship between graduates' quality and occupation outcome [7]. with a range of employability skills being highly appreciated in the labour market [8]. However the present employability skills supply isn't fitting requirement. Despite the total amount of Malaysian literature concerning employability skills and employment-related consequences, academic research studies focusing solely upon investigating the relationship between employability skills and employers (in overall or any field) are incredibly infrequent, and there's not any direct evidence in regards to the effect of employability skills on company satisfaction. Furthermore, the majority of the research doesn't identify employability skills and distinguish them by a dimension of skills.

In Feb, whilst employability skills are promoted as identified and improving the employability of graduate's skills in an assortment of fields, for example, civil engineer [9] and many more, thus higher schooling, there has been much less emphasis on researching the connections between interior design employability skills and employers' pride. However, some professional and investigators studies [10] have attempted to set a matchup between employability skills and 


\section{International Advanced Research Journal in Science, Engineering and Technology}

Vol. 6, Issue 6, June 2019

employers, these driven studied by the major thing requires more rigorous empirical signs to interpret in to clinics which solve employability problems and more attention in the sphere of investigation. As a result of this, there is a shortage of empirical research in this field and also the unexplored statistical relationship between employability skills and company's satisfaction pursuits that both the research workers since it seems that this relationship has a much greater affect graduates' long term growth compared to literature suggests. From the conversation above, to overcome this issue Examining the institution between graduate's employability skills on company's satisfaction, also to examine the result of work experience.

\section{LITERATURE REVIEW}

\section{A. Malaysian University}

Higher Education Institution that is Malaysian serves to disseminate education or knowledge, skills, exposure and experience. It intends to expand students' potential and later produce entirely incorporated graduates in terms of intellectual, spiritual, emotional as well as physiological. Once graduate, this potential human funding will likely be knowledgeable, own excellent personality, responsible and able to generate compatible family, society and state [11]. Public universities in Malaysia have increased to a total of 20 from seven in the 1990s in 2006.

A total of 28 universities also have been growing until 2011. At exactly the exact same time, you will find more than 500 other associations, including university colleges, branch campuses of both overseas and local institutions, open universities and other associations with non-university status like teacher education institutes, polytechnics and community colleges [12]. Due to this growth amount of higher education associations, the entire number of graduates increased by 249,612 graduates at 2012 into 283,627 graduates at 2016 where public university graduates climbed by 121,799 to 124,223 while private university graduates climbed from 85,669 into 97,333 at 2016 (MOHE, 2016-2012).

\section{B. Employability}

Employability is an expression that's usually utilized as a dimension by employers on graduates' marketability [15] Meanwhile, the [14] (2008) defines employability because graduate's labour market outcomes and few days jobless or possibility of jobless. Lim says that normally the graduates are having an overall total of 138 days to be jobless which can be equivalent of 4.6 weeks. This study conceptualizes employability since the capacity of the university students to be self-explanatory to become employed.

\section{Employability Skills}

Employability skills may also be called job preparation skills. Broadly speaking, employability skills are required by students to organize themselves to satisfy the requirements of many diverse jobs up on collaboration [16, 19, 20] said that employability skills might be outlined as vital skills for procuring job, including basic skills in writing, reading, arithmetic, and believing and problem-solving skills. As stated by [21], employability skill denotes the quality and private insight that a graduate need to possess. That will be to help with the employability of their graduate and also to further help the graduate to develop into worker.

A couple of researchers' states that employability skills can be really actually just a couple of achievement, understanding, and individual attitudes or qualities which indicate the patient as more competent to find the desired project and successful at career choice [23, 25, 26] additionally agrees that attitude is equally as crucial as the hard and soft skills so as to be properly used. Broadly speaking, employability skills are such elements of skills and knowledge students will need to need to equip them to satisfy employment requirements when they've completed their research studies.

\section{Human Capital Theory}

Human capital theory originates from Shultz in 1961 and updated by Becker in 1964. The theory argues that education provides human with knowledge, skills and abilities. The more educated people are, the more they are able to perform in their jobs and thus, their productivity increase [27]. This theory is the landscape for this study. 


\section{International Advanced Research Journal in Science, Engineering and Technology}

Vol. 6, Issue 6, June 2019

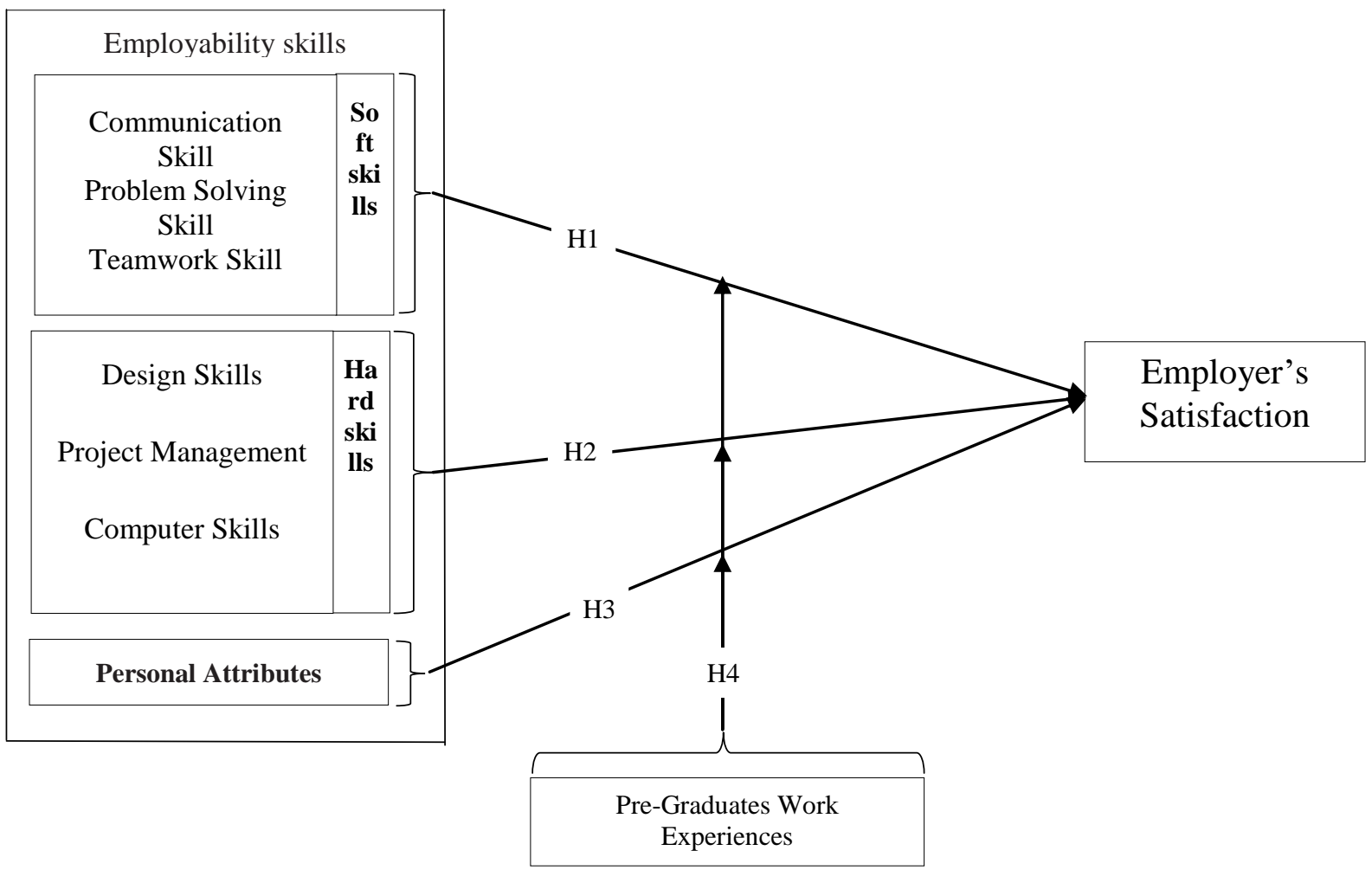

Figure1: The framework for employability skills in interior design

III.

\section{METHODOLOGY}

The researches will be a study employing a quantitative approach. The research questionnaire was developed based on previous studies and was pilot tested to twenty-six pupils of a university. The Cronbach's Alpha was calculated and the worth of more than 0.8 suggests that the things form a scale that has good internal consistency reliability. The questionnaire contains four components which are market and skills. The response scale used in this study is just five Likert scale that is 1: strongly disagree to 5: strongly agree. Employability skill in this study was analyzed according to soft skill and hard skill. Respondents were requested to evaluate the value of the skills in locating occupation. The questionnaire has been finalized and distributed to reviewers at the beginning of their lessons. Before finishing the research questionnaire, the students are given some introduction of this research and some directions on completing the questionnaire. Each respondent was given a token of admiration on the recurrence of this questionnaire. The population of this study is university students as this study intends to measure job readiness in terms of employability skills. Therefore, three public and three private universities have been chosen for its samples. Purposive random sampling method can be employed for distributing the questionnaires. Descriptive and inferential analysis were utilized to analyze the information. Descriptive analysis is conducted for the profile of the respondents and the key factors of this study. Evaluation was conducted to obtain the extent of work openness concerning employability skills between variety and sex of institutions.

\section{RESULT}

In order to estimate and validate the model, partial least squares path modelling (PLS-PM) has been implemented. This process enables the hypothesised linkages among the seven latent factors to be anticipated, as well as the extent to which they're adequately quantified by the corresponding detected indicators to be evaluated [28, 29]. PLS-PM doesn't require a very high requirement for regular distribution of the source information and works with a rather small sample size [31]. Additionally, PLS is used in national satisfaction indexes, and it is therefore an proper option for testing a research model like the one introduced here (IPQ, 1999). The applications Smart-PLS 2.0 M3 was used in this study to assess and validate this model. The measurement model will be assessed first, followed by the structural model.

\subsubsection{Convergent Validity}

The scholar has assessment of the construct validity of the model by two kinds of convergent validity and discriminant validity, in this thesis. Convergent validity is plain when each dimension item correlates strongly with its intentional theoretical construct [21]. As recommended by Fornell and Larcker (1981) in this thesis Convergent validity of the 


\title{
International Advanced Research Journal in Science, Engineering and Technology
}

\author{
Vol. 6, Issue 6, June 2019
}

low-order constructs was observed via AVE values. Sufficient convergent validity is realized when AVE value of a construct is at least 0.5 , which mean construct explains more than $50 \%$ of the variance amongst the scale indicators [21]. This study presents that the AVE for all constructs is within the range of 0.753 and 0.911 , fulfilling the 0.5 threshold demonstrating convergent validity.

\subsubsection{Discriminant Validity}

Discriminant validity which is a degree item differentiate to measure different concepts by investigative the correlations among the measures of potentially overlapping constructs, considering as second type of validity. The discriminant validity defines the extent to which each measure is more highly connected to its measures than with other construct [21]. The AVE a latent variable can be applied to set discriminant validity if this value is larger other correlation values between the latent variables [21]. There are two principles to achieve for content Discriminant Validity. First, the assessment items should show high loadings on their theoretically purposed constructs and must not load highly on other constructs [21]. Second, the measure present satisfactory discriminant validity when the square root of the AVE is larger than the inter-construct correlations [21].

Discriminant validity was observed over the correlation matrix of the constructs. When comparing the square roots of the AVE for each construct with the correlations between other constructs displays that the square root of AVE as the diagonal elements are greater than the off-diagonal correlations in rows and columns. Therefore, the discriminant validity at the constructed scale is confirmed. In short, the reliability and validity of reflective construct measures have been supported.

\subsubsection{Assessment of Coefficient of Determination $\left(R^{2}\right)$.}

The structural model was identified after tested the significance and relevance of the path coefficient. The explaining was observed by the coefficient of determination $\mathrm{R}^{2}$ values [21]. $\mathrm{R}^{2}$ appears the sum of variance in the endogenous constructs, in this study the Employers Satisfactions that is clarified by the mode. $\mathrm{R}^{2}$ values of $(0.67 /$ substantial $),(0.33 /$ moderate) \& (0.19/ weak) as [21] suggested for endogenous latent constructs in the inner model. As indicate in Table 1, the outcome of robust model with $(\mathrm{R} 2=0.482)$ or $40 \%$ of variance in Employers Satisfactions described by the first order constructs, namely soft skills, hard skills, personal attributes and Pre-Graduate Work Experience, when compared with [21] recommendations with thesis result, the explained variance of employer's satisfaction can be interpreted as moderate.

Table (1) R-square of the Endogenous latent variables

\begin{tabular}{|c|c|c|}
\hline Constructs & $\mathbf{R}^{2}$ & Outcome \\
\hline Employers Satisfactions & 0.482 & Moderate \\
\hline
\end{tabular}

\subsubsection{Assessment of Squared $\left(\mathbf{f}^{2}\right)$}

Effect size shows the relative effects of a particular exogenous latent variable on an endogenous latent construct utilising alteration in the R-square [21]. According to the chin (1998) to calculated as a rise in R-squared of the latent variable which that path in linked, proportional to the latent variable's rate of unexplained variance. f2 is calculated by employing the following formula.

$$
f^{2}=\frac{R^{2} \text { included }-R^{2} \text { excluded }}{1-R^{2} \text { included }}
$$

According to Cohen (1988) Interpreting of Effect Size $\left(\mathrm{f}^{2}\right): 1 . \mathrm{f}^{2}$ above 0.35 are considered large effect size, 2 . $\mathrm{f}^{2}$ ranging from 0.15 to 0.35 are medium effect size, $3 . \mathrm{f}^{2}$ between 0.02 to 0.15 considered small effect size, 4 . $\mathrm{f}^{2}$ values less than 0.02 are considering with $\mathrm{NO}$ effect size.

Table (2) Result of Effect Size

\begin{tabular}{|c|c|c|}
\hline Constructs & \multicolumn{2}{|c|}{ SE } \\
\hline & $\boldsymbol{\beta}^{\mathbf{a}}$ & $\mathbf{f}^{2}$ \\
\hline SS & 0.304 & 0.083 \\
\hline HS & 0.231 & 0.049 \\
\hline PA & 0.136 & 0.022 \\
\hline WX & 0.175 & 0.038 \\
\hline
\end{tabular}




\section{International Advanced Research Journal in Science, Engineering and Technology}

Vol. 6, Issue 6, June 2019

According to Table 2 regarding the relationship between the exogenous variables and employer's satisfaction, the analysis reveals that SS, HS, PS and WX significantly and positively affect employer's satisfaction with small effect size $\left(\mathrm{f}^{2}=0.083, \mathrm{f}^{2}=0.049, \mathrm{f}^{2}=0.022 \& \mathrm{f}^{2}=0.038\right)$ respectively.

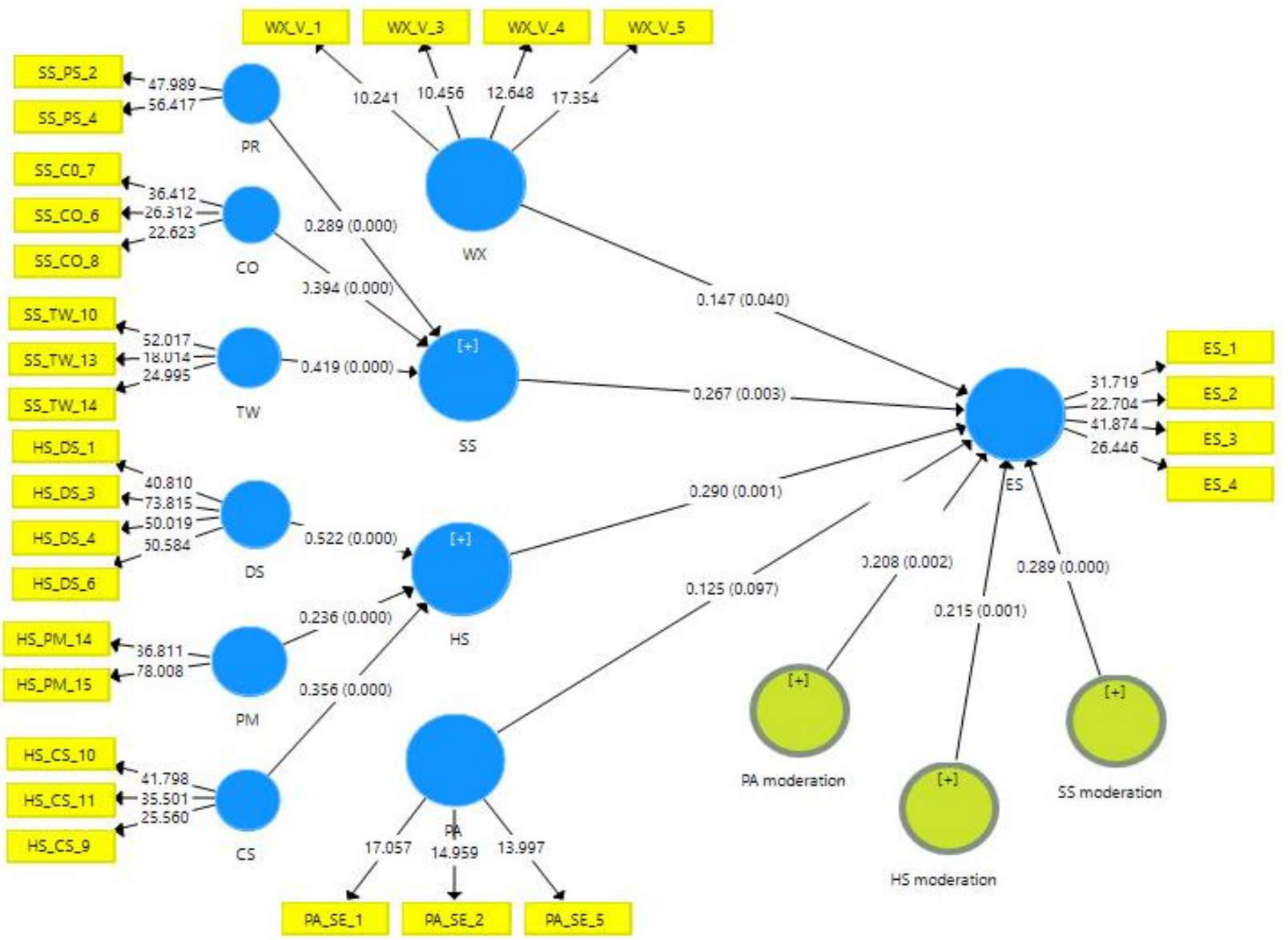

Figure (2) the measurement of Structural Model with (indirect effects)

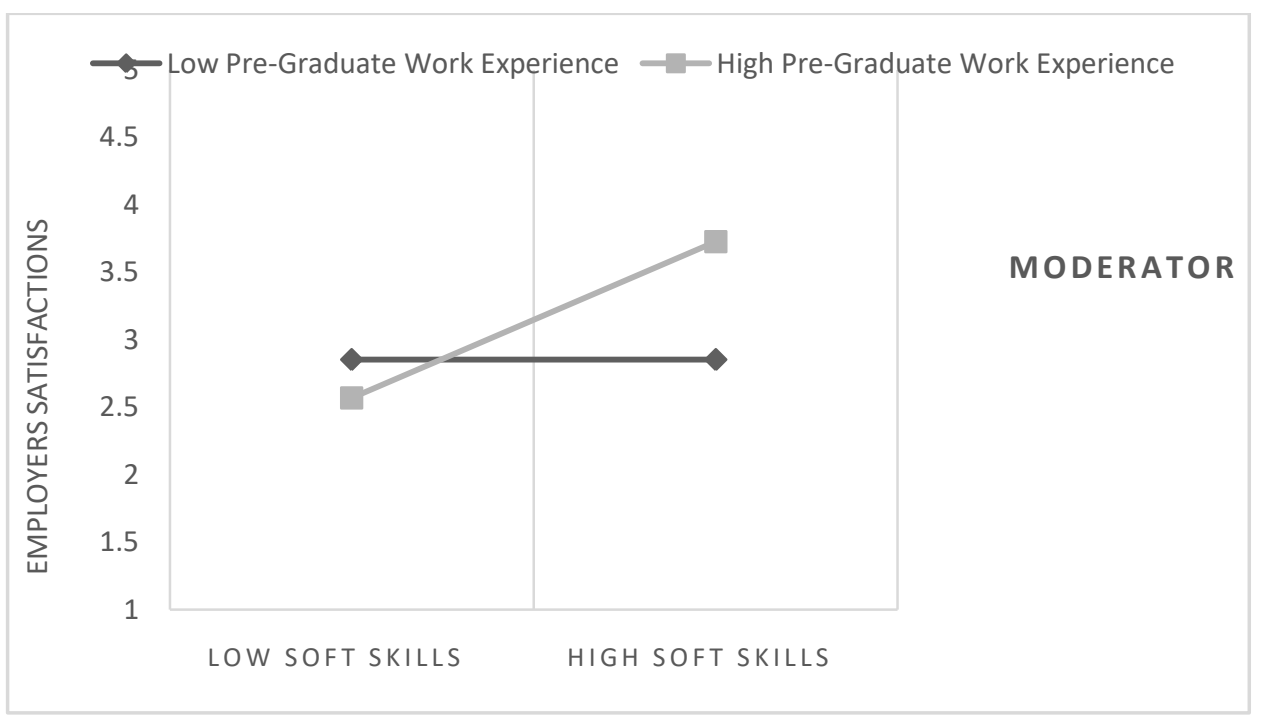

Figure (3) Slope Plot SS*ES $\rightarrow$ WX

The figure (3) represent there is Pre-Graduate Work Experience strengthens the positive relationship between hard skills (HS) and Employers Satisfactions (ES). 


\section{International Advanced Research Journal in Science, Engineering and Technology}

Vol. 6, Issue 6, June 2019

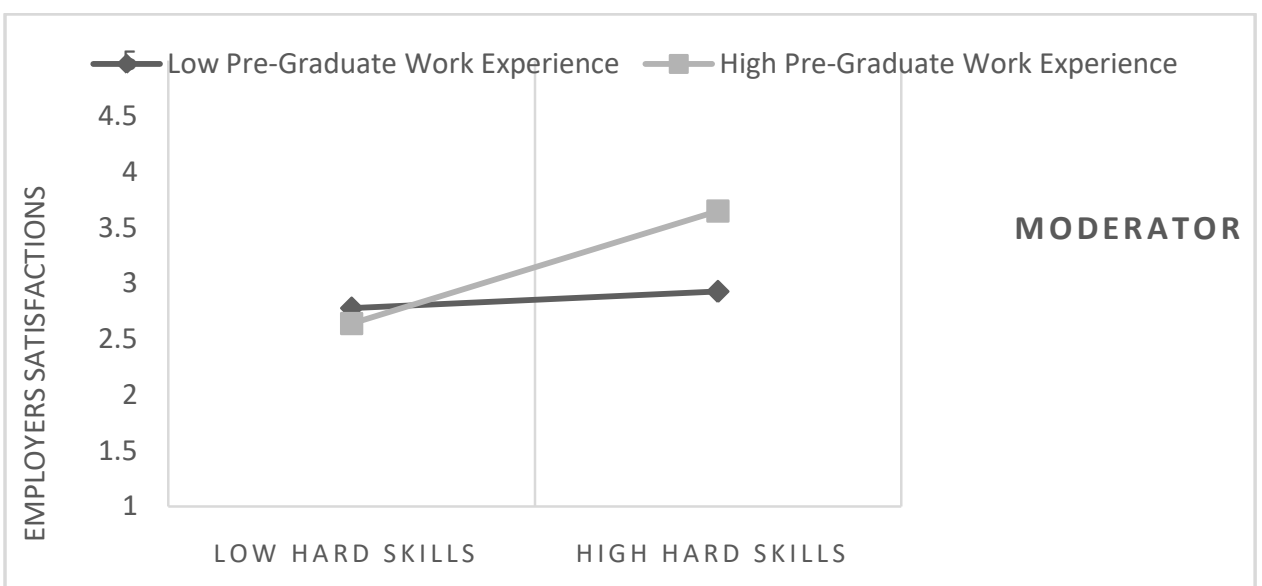

Figure (4) Slope Plot HS*ES $\rightarrow$ WX

The figure (4) represent there is Pre-Graduate Work Experience strengthens the positive relationship between Personal attributes (PA) and Employers Satisfactions (ES).

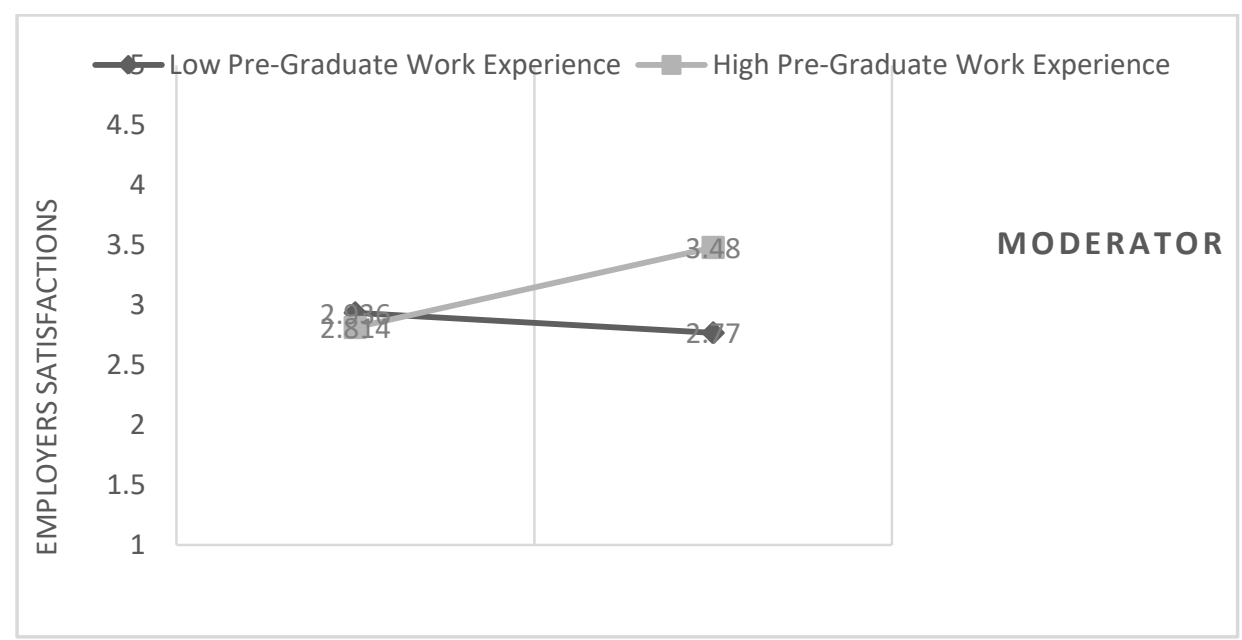

Figure (5) Slope Plot PA*ES $\rightarrow$ WX

The Result of Hypothesised Relationships and Discussion

As represented above the structural model estimate, Table (3) represents that all suggest hypothesis are supported.

Table (3) Summary the Result of All Hypothesise Relationships.

\begin{tabular}{|l|c|}
\hline Hypothesise & Result \\
\hline H1: Soft skills and employer's satisfaction are positivity related. & Supported \\
\hline H2: Hard skills and employer's satisfaction are positivity related. & Supported \\
\hline H3. Personal Attributes and employer's satisfaction are positivity related. & Supported \\
\hline $\begin{array}{l}\text { H4. Pre-Graduate Work Experience and employer's satisfaction are positivity related. } \\
\text { S5: Pre-Graduate Work Experience moderator the relationship between soft skills and employer's } \\
\text { satisfaction. }\end{array}$ & Supported \\
\hline $\begin{array}{l}\text { H6: Pre-Graduate Work Experience moderator the relationship between hard skills and employer's } \\
\text { satisfaction. }\end{array}$ & Supported \\
\hline $\begin{array}{l}\text { H7: Pre-Graduate Work Experience moderator the relationship between Personal Attributes and } \\
\text { employer's satisfaction. }\end{array}$ & Supported \\
\hline
\end{tabular}




\title{
International Advanced Research Journal in Science, Engineering and Technology
}

\author{
Vol. 6, Issue 6, June 2019
}

\section{A. Measurement model}

Discriminant validity was observed over the correlation matrix of the constructs as showed in Table (1). When comparing the square roots of the AVE for each construct with the correlations between other constructs, outcome in Table (2) displays that the square root of AVE as the diagonal elements are greater than the off-diagonal correlations in rows and columns. therefore, the discriminant validity at the construct scale is confirmed. in shortly, the reliability and validity of reflective construct measures have been supported. Reliability was initially assessed for each item, and the obtained loadings were mainly above 0.7 , indicating good item reliability (Table 1). Guidelines suggest that the standardised loading for each item should be higher than 0.7 [33]. However, an item reliability of 0.5 is still acceptable [34]. Regarding composite reliability, which measures the extent to which a latent variable is adequately represented by its indicators, all values exceeded the recommended 0.7 threshold [35]. The measurement model was further evaluated regarding convergent validity and discriminant validity. In this respect, [36] claim that convergent validity is demonstrated if the indicators present a t-value (bootstrap) that is significant for the corresponding latent variable; in other words, it must be higher than 1.96 (considering a 95\% confidence interval). In our study, this result is verified for all items (Table 2). The average variance extracted (AVE) was also used to access convergent validity; according to Dillon and Goldstein (1984), it should exceed 0.5. Table (2) indicates that the AVE values range from 0.47 to 0.8. Only one construct employability did not exceed the 0.5 threshold value. However, all its loadings exceeded the level and are statistically significant, and so it was considered to have sufficient convergent validity. To assess discriminant validity, the average variance extracted for each construct must be higher than the squared correlations between the construct and all the other constructs in the model [27] This analysis indicates adequate discriminant validity, apart from three situations regarding employability. Nevertheless, the analysis of the cross-loadings, which are another measure of discriminant validity, shows that all items' loadings are higher than all of their cross-loadings, dissipating any uncertainty as far as employability is concerned.

\section{B. Structural model}

we provide the estimated path coefficients and corresponding p-values for the structural model. This provides evidence that employability is a key antecedent of image and that image is the most important antecedent of satisfaction. As can be observed, nine of the twelve path coefficients are statistically significant at a $95 \%$ confidence level. Within each ellipse, the R2 values are presented. The latent variable satisfaction reports the greatest R2 (0.754). Loyalty also reports an R2 value superior to 0.67 , indicating the adequacy of the model and data for the issue under study. Note also the high R2 (0.525) associated with the latent variable image. The dashed grey lines represent the hypotheses involving direct effects that are rejected.

\section{Testing the research hypotheses}

The results shown in Fig. 2 allow the testing of the hypotheses that involve direct relationships between latent variables. All tests were conducted to a 95\% confidence level. Some hypotheses were rejected: H1 (p40.05), H3 (p40.10), and H7 (p40.10). To test H10, the indicators relating to non-human elements were dropped, and the model was re-estimated considering only the indicators related to human elements. This procedure produced a significant path diagram estimate of 0.2281 (po0.01), which validated H10.

\section{DISCUSSION}

The results indicated the Interior design graduates ought to be well equipped with all the subsequent knowledge including soft skills (communication skills, problems solving skills and teamwork skills), hard skill (style skills, project management skills and computer skills) and personal attributes. On the other hand, the next knowledge such as functional training, company law, research procedures, business plan, technology issues, economics and ethics ought to be given greater emphasis for those graduates too. The findings of the study were supported by the findings from this former researcher [39, 40, 41] and enlarge the comprehension of this Malaysia interior design' perceptions and employers regarding interior design graduates in Malaysia. Design students should think about the qualities which are considered to be significant by design to be integrated into the planned program accordingly. Primarily, this study offers proof that interior designer and employers perceived equally on the basic attributes that have to be considered from the program within the instructional system. Employers also suggested that interior design graduates revealed top skills in a style program system, written and oral communication skills, negotiating skills and conclusion ability. Layout graduates must also demonstrate high skills in research writing, managerial ability, presentation ability, solvingproblem and critical thinking. However, employers may think that interior design graduates lack social skill. The study also discovered that employers believed that the degree of style graduates' skills had been significant, particularly in implementing analytical methods; critical thinking and can operate independently. Graduates of interior design must also reveal their capacity in handling clients, ability to apply theoretical understanding, execute technological evaluation and re-evaluation, capable of functioning in class and technology and company strategy. The findings also suggest that employers need work-ready graduates using pre-graduate function expertise. These findings also supported 


\title{
International Advanced Research Journal in Science, Engineering and Technology
}

\author{
Vol. 6, Issue 6, June 2019
}

previous study, for example, [38, 42] which implied that employers think graduates have clear expectations of life within the company world and are usually deficient in social skills. While combined education programs can offer an ideal car to bridge the difference between the area of work and also the area of instruction, curriculum developers have to be cautious and make sure they know the area of the job, and so the competencies required for interior design graduates.

Since the focus changes from a job into employability, graduates need to realize their approach to work is equally as critical as the job itself. Additional their willingness and ability to undertake expert training and development during their working lifetime isn't just anticipated but will probably be a requirement for lifelong perform.

A significant contribution that concerted interior design education programs will cause pupils' future job life will be to assist them to realize that the workplace is merely a distinct learning establishment compare to high education instruction. It's a location where the program is un-stated and also the learning outcomes uncertain but, significantly, it's a location where they need to take responsibility for identifying their learning needs and do something on it, always.

The results clearly indicated that Interior design graduates should be well equipped with the following knowledge such as soft skills (communication skills, problems solving skills and teamwork skills), hard skill (design skills, project management skills and computer skills) and personal attributes. However, the following knowledge such as practical training, business law, research methods, business strategy, technology topics, ethics and economics should be given more emphasis for the graduates as well. The results of this study support the findings of the previous research [33] and expand the understanding of the Malaysia interior design' perceptions and employers toward interior design graduates in Malaysia. Design students should consider the qualities that are perceived to be important by practicing designing to be incorporated into the design curriculum accordingly. Specifically, this study provides evidence that interior designer and employers perceived alike on the key qualities that must be considered in the curriculum within the educational system.

Employers also indicated that interior design graduates showed high skills in design application system, written and oral communication skills, negotiating skills and decision skill. Design graduates should also show high skills in report writing, supervising skill, presentation skill, solving problem and critical thinking. However, the employers might believe that interior design graduates lack of interpersonal skill. The study also found that employers perceived that the level of design graduates' abilities were high, especially in applying analytical techniques, critical thinking and able to work independently. Graduates of interior design should also show their ability in managing sub-ordinates, ability to apply theoretical knowledge, perform technological assessment and re-evaluation, able to work in group and technology and business strategy.

The findings also indicate that employers want 'work-ready' graduates with pre-graduate work experience. These findings also confirmed previous study like [40], which suggested that employers believe graduates have unrealistic expectations of life in the business world, and are generally deficient in interpersonal skills. While cooperative education programs can provide an ideal vehicle to bridge the gap between the world of work and the world of education, curriculum developers must be vigilant and ensure that they understand the world of work, and thus the competencies demanded of interior design graduates. As the focus shifts from 'employment' to 'employability', today's graduates will need to understand that their attitude to work is as important as the work itself. Furthermore, their ability and willingness to undertake professional development and training throughout their working life is not only expected, but will be a pre-requisite for lifelong work. An important contribution that cooperative interior design education programs can make to students' future work life is to help them to understand that the workplace is simply a different learning institution compare to higher education learning. It is a place where the curriculum is un-stated and the learning outcomes unclear but, importantly, it is a place where they must take responsibility for identifying their own learning needs and then do something about it, continuously.

\section{CONCLUSION}

The results of the study also suggest that the perspectives of individuals currently working in the industry with interior design graduate would provide valuable insight into additional qualities needed to succeed. Therefore, these individuals should be included in future studies. Finally, the results also indicate that knowledge in the areas of human resources management, marketing management, financial and accounting management, information technology, communication and leadership skills are relevant to all accounting graduates. 


\section{International Advanced Research Journal in Science, Engineering and Technology}

Vol. 6, Issue 6, June 2019

\section{RESEARCH LIMITATION AND FUTURE DIRECTION}

It is recommended that the curriculum design programs should include all of the broad competencies provided in the study. However, it is also recommended that further investigation be conducted on specific qualities areas. It is also recommended that an examination of international programs in interior design programs (if any exist) may be useful in determining additional qualities. Based on the research results and discussion, this study has paved several suggestions for future research. a) The sample of the study could be extended to a larger population, for instance other types of organisation and sectors. This could possibly be more meaningful to grasp some understanding and knowledge of the empirical linkages of all variables of interest in this study. b) Expanding the population to different groups of employers, sectors and employees; for instance, management and professional groups, other industrial, banking or government sectors and employees. This could enhance the understanding on how the interior design graduates possessed the qualities and how they perform their job in comparison to various group. c) Future studies also should incorporate other predictors of job performance because this behavioural outcome is attributed to many factors, not limited to the qualities of the employers. In fact, there are many other situational predictors of job performance that should be scrutinised in future studies, such as commitment, job satisfaction, job involvement and role identity. d) Future research should also consider the role of intervening variables that could play the role in the relationship between design graduates' qualities and job performance. For instance, future research might incorporate the mediating variable (eg, training) or moderating variable (eg, firm size) that might enhance and increase the job performance.

\section{REFERENCES}

[1]. Alves, H., and Raposo, M. (2007a). Conceptual model of student satisfaction in higher education. Total Quality Management, 18(5), 571-588.

[2]. Alves, H, Raposo, M. (2007b). Student satisfac index in Portuguese public higher education. The Service Industries Journal, 27(6), 795-808.

[3]. Anctil, Eric., (2008). Selling Higher Education: marketing and advertising America's Colleges and Universities: ASHE Higher Education Report, Vol. 34 (no. 2). Las Vegas: ASHE Higher Education Report Series.

[4]. Anderson, E., and Sullivan, V. (1993). The antecedents and consequences of customer satisfaction for firms. Marketing Science, 12, 125-143.

[5]. Belanger, C., Mount, J., and Wilson, M. (2010). Institutional image and retention. Tertiary Education and Management, 8(3), 217-230.

[6]. Brown, R., and Mazzarol, T. (2009). The importance of institutional image to student satisfaction and loyalty within Higher Education. Higher Education, 58, 81-95.

[7]. Butt, B, Rehman, K. (2010). A study examining the students satisfaction in Higher Education. Procedia Social and Behavioral Sciences, 2, 5446-5450.

[8]. Campostrini, S., and Gerzeli, S. (2007). Informative sources for the evaluation of the university education effectiveness in Italy. In L. Fabbris (Ed.), Effectiveness of university education in Italy. Employability, competences, human capital (pp. 2-9). Padua: Physica-Verlag.

[9]. Cassel, C., and Eklof, J. A. (2001). Modelling customer satisfaction and loyalty on aggregate levels: Experience from the ECSI pilot study. Total Quality Management, 12(7and8), 834-841.

[10]. Catramby, T. C., and Costa, S. R. (2004). Qualificação profissional em turismo como fator de competitividade do setor. Caderno Virtual de Turismo, 4(3), 26-34

[11]. Chiandotto, B., Bini, M., and Bertaccini, B. (2007). Quality assessment of the university educational process: An application of the ECSI model. In L. Fabbris. (Ed.), Effectiveness of university education in Italy. Employability, competences, human capital (pp. 43-54). Padua: Physica-Verlag.

[12]. Chin, W., and Newsted, P. (1999). Structural equation modeling analysis with small samples using partial least squares. In R. Hoyle (Ed.), Statistical strategies for small sample research (pp. 307-342). Thousand Oaks, CA: Sage.

[13]. Chin, W. (1998). The partial least squares approach to structural equation modeling. In G. A. Marcoulides (Ed.), Modern methods for business research (pp. 295-336). London: Lawrence Erlbaum Associates.

[14]. 1Chitty, B. and Soutar, G. (2004). Is the European Customer Satisfaction Index Model Applicable to Tertiary Education? ANZMAC 2004 Conference Wellington (pp. 1-7). Australian and New Zealand Marketing Academy.

[15]. De Vos, A., De Hauw, S., and Van der Heijden, B. (2011). Competency development and career success: The mediating role of employability. Journal of Vocational Behavior, 79, 438-447.

[16]. Dillon, W., and Goldstein, M. (1984). Multivariate analysis. Methods and applications. New York: Wiley.

[17]. Engberg, M.E (2007). Educating the workforce for the 21 st century: a cross-disciplinary analysis of the impact of the undergraduate experience on students' development of a pluralistic orientation. Research in Higher Education, 3(48), 283-317.

[18]. Eskildsen, J., Martensen, A., Gronholdt, L., and Kristensen, K. (2000). Benchmarking student satisfaction in higher education based on the ECSI methodology. sinergie raporti di ricerca, 9, 385-402.

[19]. Fornell, C., and Larcker, D. (1981). Structural equation models with unobservable variables and measurement error: Algebra and statistics. Journal of Marketing Research, 18(3), 328-388.

[20]. Gedye, S., Fender, E., and Chalkley, B. (2004). Students' undergraduate expectations and post-graduation experiences of the value of a degree. Journal of Geography in Higher Education, 28(3), 381-396.

[21]. Gefen, D., and Straub, D. (2005). A practical guide to factorial validity using PLS-graph: Tutorial and annotated example. Communications of the Association for Information Systems, 16(25), 91-109.

[22]. González, M., Comesaña, L., and Brea, J. (2007). Assessing tourist behavioral intentions through perceived service quality and customer satisfaction. Journal of Business Research, 60, 153-160. Hair, J., Ringle, C., and Sarstedt, M. (2011). PLS-SEM: Indeed a silver bullet. Journal or Marketing Theory and Practice, 19(2), 139-151.

[23]. Hartman, D., and Schmidt, S. (1995). Understanding student/alumni satisfaction from a consumer's perspective. Research in Higher Education, $36(2), 197-217$

[24]. Harvey, L. (2001). Defining and measuring employability. Quality in Higher Education, 7(2), 97-109.

[25]. Harvey, L. (2010). New realities: The relationship between higher education and employment. Tertiary Education and Management, $6(1), 3-17$.

[26]. Hemsley-Brown, J. (2012). 'The best education in the world': Reality, repetition or cliché? International students' reasons for choosing an English University. Studies in Higher Education, 37(8), 1005-1022. 


\section{International Advanced Research Journal in Science, Engineering and Technology}

Vol. 6, Issue 6, June 2019

[27]. Hennig-Thurau, T., Langer, M., and Hansen, U. (2001). Modeling and managing student loyalty: An approach based on relationship quality. Journal of Service Research, 4, 331-344.

[28]. Hillage, J., and Pollard, E. (1998). Employability: Developing a framework for policy analysis. EfEE Research Briefing, 85, 85.

[29]. Johnson, M., Gustafsson, A., Andreassen, T. W., Lervik, L., and Cha, J. (2001). The evolution and future of national customer satisfaction index models. Journal of Economic Psychology, 22, 217-245.

[30]. Kivinen, O., and Nurmi, J. (2007). Job requirements and competences: do qualifications matter? In U. Techler (Ed.), Careers of university graduates (pp. 131-142). Kassel: Springer.

[31]. Knight, P., and Yorke, M. (2003). Employability and good learning in higher education. Teaching in Higher Education, 8(1), 3-16.

[32]. Kohler, J. (2004). The bologna process and employability: The impact of employability on curricular development. A key objective of academic studies and for academic institutions. Conference Bled/Slovenia (p. 1-21). Bled/Slovenia: s.e.

[33]. Kristensen, K., Kanji, G., and Dahlgaard, J. (1992). On measurement of customer satisfaction. Total Quality Management, 3(2), $123-128$.

[34]. Kristensen, K., Martensen, A., and Gronholdt, L. (2000). Customer satisfaction measurement at post Denmark: Results of application of the european customer satisfaction index methodology. Total Quality Management, 11(7), 1007-1015.

[35]. Kristensen, K., Martensen, A., and Gronholdt, L. (1999). Measuring the impact of buying behaviour on customer satisfaction. Total Quality Management 10(4/5), 602-614.

[36]. Kurtz, D., Clow, K., Ozment, J., and Ong, B. (1997). The antecedents of consumer expectations of services: An empirical study across four industries. The Journal of Services Marketing, 11(4), 230-248.

[37]. Martensen, A., Grønholdt, L., Eskildsen, J., and Kristensen, K. (2000). Measuring student oriented quality in higher education: Application of the ECSI methodology. Sinergie Rapporti di Ricerca, 9, 371-383.

[38]. Mason, G., Williams, G., and Cranmer, S. (2009). Employability skills initiatives in higher education: What effects do they have on graduate labour market outcomes?. Education Economics, 17(1), 1-30.

[39]. Vinzi, V., Chin, W., Henseler, J., and Wang, H. (2010). Handbook of partial least squares. Concepts, methods and applications. Heidelberg: Springer. Vrontis, D.,

[40]. Thrassou, A., and Melanthiou, Y. (2007). A contemporary higher education student-choice model for developed countries. Journal of Business Research, 60, 979-989.

[41]. Webb, D., and Jagun, A. (1997). Customer care, customer satisfaction, value, loyalty and complaining behavior: validation in a UK university setting. Journal of Consumer Satisfaction, Dissatisfaction and Complaining Behavior, 10, 139-151.

[42]. Yorke, M. (2004). Employability in the undergraduate curriculum: some student perspectives. European Journal of Education, $39(4), 109-427$. Zeithaml, V. (1987). Defining and relating price, perceived quality and perceived value (Report no. 87-101). Cambridge: Marketing Science Institute.

[43]. Heidelberg: Springer. Vrontis, D., Thrassou, A., and Melanthiou, Y. (2007). A contemporary higher education student-choice model for developed countries. Journal of Business Research, 60, 979-989.

[44]. Webb, D., and Jagun, A. (1997). Customer care, customer satisfaction, value, loyalty and complaining behavior: validation in a UK university setting. Journal of Consumer Satisfaction, Dissatisfaction and Complaining Behavior, 10, 139-151.

[45]. Yorke, M. (2004). Employability in the undergraduate curriculum: some student perspectives. European Journal of Education, 39 (4), $109-427$. Zeithaml, V. (1987). Defining \& relating price, perceived quality \& perceived value (R.no. 87-101). Cambridge: Marketing Science Institute. 